OPEN ACCESS

Edited by:

Vance L. Trudeau,

University of Ottawa, Canada

Reviewed by:

Carol F. Elias,

University of Michigan, United States Ben Nephew,

Worcester Polytechnic Institute,

United States

*Correspondence: Gemma Casadesus gcasades@kent.edu

Specialty section:

This article was submitted to Neuroendocrine Science,

a section of the journal

Frontiers in Endocrinology

Received: 16 May 2018

Accepted: 28 August 2018

Published: 24 September 2018

Citation:

Bhatta S, Blair JA and Casadesus G (2018) Luteinizing Hormone Involvement in Aging Female Cognition: Not All Is Estrogen Loss.

Front. Endocrinol. 9:544.

doi: 10.3389/fendo.2018.00544

\section{Luteinizing Hormone Involvement in Aging Female Cognition: Not All Is Estrogen Loss}

\author{
Sabina Bhatta ${ }^{1}$, Jeffrey A. Blair ${ }^{1}$ and Gemma Casadesus ${ }^{1,2 *}$ \\ ${ }^{1}$ School of Biomedical Sciences, Kent State University, Kent, $\mathrm{OH}$, United States, ${ }^{2}$ Department of Biological Sciences, Kent \\ State University, Kent, $\mathrm{OH}$, United States
}

Pervasive age-related dysfunction in hypothalamic-pituitary-gonadal (HPG) axis is associated with cognitive impairments in aging as well as pathogenesis of age-related neurodegenerative diseases such as the Alzheimer's disease (AD). As a major regulator of the HPG axis, the steroid hormone estrogen has been widely studied for its role in regulation of memory. Although estrogen modulates both cognition as well as cognition associated morphological components in a healthy state, the benefits of estrogen replacement therapy on cognition and disease seem to diminish with advancing age. Emerging data suggests an important role for luteinizing hormone $(\mathrm{LH})$ in CNS function, which is another component of the HPG axis that becomes dysregulated during aging, particularly in menopause. The goal of this review is to highlight the current existing literature on LH and provide new insights on possible mechanisms of its action.

Keywords: luteinizing hormone, luteinizing hormone receptor, cognition, menopause, estrogen, ovariectomy, inverse relationship

\section{INTRODUCTION}

Our ability to successfully treat midlife diseases has increased human longevity as well as the prevalence of age-associated neurodegenerative diseases such as the Alzheimer's disease (AD). While a small percentage of $\mathrm{AD}$ is precipitated by dominant mutations, the majority is sporadic and is highly associated with environmental/life-style choices as well as the physiological aging process. In fact, aging is the strongest risk factor for development for $\mathrm{AD}$, the most common form of dementia (1-3). As baby boomers age, millions of people are at risk for $\mathrm{AD}$ and other cognitive diseases. This is especially relevant as the number of $\mathrm{AD}$ diagnosis is expected to rise from current 5.7 million to 14 million by 2050 , and the cost of disease is projected to rise to 1.1 trillion dollars creating a broad economic and social impact. Therefore, identifying therapeutic targets to delay, modify, or cure the disease is of paramount importance.

Menopause, a hallmark of aging in women, is associated with dysfunctions in the hypothalamicpituitary-gonadal (HPG) axis and is implicated in the pathogenesis of AD. Age-related declines in reproductive hormones lead to a disarray of the HPG axis as it is tightly regulated by positive and negative feedback loops involving gonadotropin releasing hormone $(\mathrm{GnRH})$, gonadal steroids, and gonadotropins. The loss of any component leads to significant dysregulation of the system and any type of hormonal imbalance likely affects homeostasis resulting in functional decline throughout 
the body, including the brain (4-8). In fact, these declines in gonadal hormones, and associated increases in gonadotropins such as LH are implicated in cognitive dysfunction in aging as well as the pathogenesis of age-related disorders such as AD. This is particularly relevant for women as they have two-fold higher risk for development of $\mathrm{AD}$ after menopause compared to men.

\section{HORMONE REPLACEMENT THERAPY (HRT) FOR COGNITION AND AD}

Several studies attribute increased risk of AD to the menopausal loss of estrogen $(9,10)$ and considered estrogen replacement a promising therapeutic avenue to reduce the risk of AD (1114). This was initially supported by early epidemiological studies identifying strong relationships between estrogen therapy in post-menopausal women and reductions in multiple types of memory decline, specifically, in menopausal women with and without $\operatorname{AD}(15,16)$.

Clinically, estrogen replacement or HRT showed initial promise in smaller clinical retrospective (17-20) and prospective studies (21-23). However, a large scale, randomized, doubleblind placebo-controlled trial, women's health initiative WIH found no overall cognitive benefits. While the use of estrogen immediately or after a smaller delay following onset of menopause was effective, HRT in women at least 15 years after onset of menopause slightly increased the risk of dementia instead (24-26). This discrepancy in actions of estrogen on memory and dementia risk lead several groups to hypothesize that a "critical period" may exist following onset of menopause where estrogen can confer benefits, beyond which it is ineffective and may instead exert harmful effects (27-31). These clinical observations were further supported by pre-clinical work in ovariectomized rodents (32) and primates (33) providing support for the existence of a critical window for the initiation of estrogen for optimal enhancement of cognitive function (34).

One mechanism purported to underlie the ineffectiveness of estrogen treatment beyond a critical period is the "healthy cell bias" wherein estrogen is beneficial to healthy cells, but detrimental to unhealthy ones $(35,36)$. This was further supported by the fact that critical plasticity and cognition related proteins such as BDNF (37) and the cholinergic system (38) differ in young and old rats. Based on the above theory, more recent clinical randomized trials addressed the potential benefit of estrogen therapy considering timing of replacement. Unfortunately, these studies have yielded little support for this hypothesis (39-42). Together, these data suggest that while estrogen is relevant and important for CNS function and structure during the reproductive periods, aspects beyond estrogen loss contribute to age-related menopausal dysfunction.

\section{INVOLVEMENT OF LUTEINIZING HORMONE (LH) IN CNS FUNCTION AND AD}

Accumulating evidence supports a role for $\mathrm{LH}$ in regulating cognition and $\mathrm{AD}$-related parameters. $\mathrm{LH}$, a gonadotropin hormone released from the anterior pituitary, functions to stimulate the production of sex steroids, which in turn negatively regulate hypothalamic GnRH release and further production of LH. In the absence of sex steroids providing negative feedback, LH levels drastically increase, as observed following menopause and andropause. Peripheral levels of LH increase three-fold in post-menopausal women (43) and two-fold in aging men (44). Importantly, these increases in peripheral $\mathrm{LH}$ levels correlate to cognitive deficits in aging men and women $(45,46)$ as well as AD patients (47-51). In fact, increased levels of peripheral LH in AD patients is associated with exacerbated pathology and cognitive deficits (50-52). Additionally, increased LH is correlated with increased plasma $A \beta_{1-40}$ and $A \beta_{1-42}$ levels in subjective memory complainers, suggesting LH may play a progressive role in early preclinical stages (51).

In rodents, earlier studies demonstrated that over-expression of $\mathrm{LH}$ in transgenic mice (53), or exogenous treatment with human LH (54) without any estrogen manipulations, impaired working memory. These studies are supported by work showing that chronic elevations in peripheral levels through exogenous application of the LH analog, human chorionic gonadotropin (hCG), results in similar attenuation of working memory as well as increases in total brain amyloid- $\beta_{1-40}$ in a mouse model of $\operatorname{AD}(55,56)$. Moreover, peripheral increase in hCG is capable of reversing estrogen associated benefits in spatial memory $(55,56)$.

Several studies involving pharmacological downregulation of peripheral $\mathrm{LH}$ after ovariectomy also support a role for LH in cognition and plasticity. To this end, work utilizing either GnRH super-agonist (57-60) or competitive antagonists (61-64) of the GnRH receptor reverse cognitive deficits (57$64)$ and neuronal plasticity loss $(59,60)$ in the absence of estrogen replacement. For example, several studies from our lab using GnRH super-agonist, leuprolide acetate, improved function in ovariectomized $\mathrm{C} 57 \mathrm{BL} / 6 \mathrm{~J}$ mice $(58,60)$ as well as aged-ovariectomized $3 \times \mathrm{Tg} \mathrm{AD}$ mice (59). Furthermore, these benefits were associated with activation of signaling cascades associated with long term potentiation (LTP), the cellular basis of learning and memory, Bryan et al. (58) in the absence of $\mathrm{AD}$ pathology (59), further supporting a direct role of LH-related mechanisms on cognition. More importantly, a key finding was that pharmacological reductions in peripheral levels of $\mathrm{LH}$ lead to cognitive improvements and rescue of dendritic spine density without any dependence on timing of treatment onset (60). This raises the exciting possibility that LH may provide an additional therapeutic target for rescuing cognitive and structural deficiencies associated with menopause, aging, and $\mathrm{AD}$.

While there is no clinical data to support the benefits of peripheral downregulation of LH in menopausal women, clinical data in $\mathrm{AD}$ patients support its validity (65). A small, phase II, randomized, clinical trial, in female patients with moderate $\mathrm{AD}$, showed that leuprolide acetate stabilized cognitive function in a subgroup treated with an acetylcholinesterase inhibitor, Aricept. Given Aricept is the primary treatment option for AD patients, these data are encouraging. However, while clinical and preclinical studies show promise for LH-related therapeutics, the 
mechanisms underlying these effects remain unknown to date. In the next sections, we highlight a potential mechanism of action of these therapies in relation to signaling and function of the $\mathrm{LH}$ receptor.

\section{LH SIGNALING AND COGNITION}

LH as well its receptor LHR are expressed in the CNS (66-69). Importantly, LHR is present in regions associated with learning and memory (68-70). Similarly, LHR is also expressed in the choroid plexus, ependymal cells of the third, fourth and lateral ventricles as well as the area postrema (68), which are areas involved in production and circulation of cerebrospinal fluid CSF as well as blood brain barrier transport, suggesting a potential modulatory role of LHR in BBB permeability.

The LHR is a G-protein-coupled receptor involved in production of sex steroids in the gonads through Gs cAMP/PKA, ERK and Gq PLC pathways. $\mathrm{G}_{\mathrm{s}}$ signaling results in phosphorylation of MAPK and CREB, while $G_{q}$ induces intracellular $\mathrm{Ca}^{2+}$ release and activation of several protein kinases such as PKA and CAMKII (71-74). LHR activated cAMP/PKA signaling cascades in the immortalized cultures of hippocampal and hypothalamic neurons in vitro $(75,76)$. Interestingly, these signaling cascades downstream of LHR are associated with gene expression and structural changes that are the hallmark of synaptic plasticity and memory formation in the CNS (77-80) and induction of LTP (81-84). Furthermore, active kinases trigger activation of transcriptional factors such as MAPK and CREB leading to gene expression and structural remodeling of the synapse. This ultimately leads to enhanced synaptic transmission and BDNF production, as well as plasticity of dendritic spines $(79,85-87)$. However, as previously discussed above, downregulation of peripheral $\mathrm{LH}$ in the OVX model lead to CAMKII autophosphorylation at Thr 286 and CAMKII dependent GluR1 Ser 831 phosphorylation (58), inhibition of GSK3 $\beta$ and upregulation of $\beta$-catenin in 3X Tg mouse model of AD (59), and improved cognitive function. Based on the known canonical signaling cascades ascribed to the LHR, these data, at least indirectly, suggest activation rather than inhibition of the LHR, thus, in conflict with the prevalent idea that $\mathrm{LH}$ signaling in the CNS is detrimental.

The idea that LH signaling in the CNS is detrimental stems from the supposition that $\mathrm{LH}$ crosses the blood-brain-barrier (BBB); however, $\mathrm{LH}$ is a large glycoprotein that is unlikely to penetrate the BBB without a transporter molecule. Furthermore, both human and animal studies show contradictory evidence on whether hCG or LH can cross the BBB. One study showed some permeability of hCG into CNS when administered at supra-physiological levels (88) while another did not (89). Moreover, studies show hCG is not BBB permeable in human choriocarcinomas models until a high threshold is reached $(90,91)$, especially in patients with normal levels of plasma LH (92). These data suggest that hCG and LH may not be permeable in normal or OVX conditions, thus, the supposition that the LHR is detrimental is difficult to reconcile.

\section{BRAIN-SPECIFIC LH AS MECHANISM FOR LHR-MEDIATED CNS FUNCTION}

Several earlier studies have demonstrated the expression of $\mathrm{LH}$ in the brain of various species $(59,66,67)$, as well as its ability to modulate synaptic function (93-95), neurogenesis (96), and behavior $(59,88,97,98)$. In vitro, administration of the $\mathrm{LH}$ analog hCG, which binds and activates the LHR similarly to LH $(99,100)$, stimulates neurite outgrowth in rat neuronal culture and differentiation in PC12 cells through activation of the erk/MAPK pathway $(99,101)$. Erk/MAPK is a pathway that is critical for memory function and plasticity (78). Similarly, LHR activation in vitro also leads to stem cell differentiation (102), and protection against excitotoxicity in primary neurons (103).

LHR transcripts as well as functional receptors have been found in neurons and glial cells in vitro $(94,95)$. LHR was functional in vitro in neurons cultured at embryonic day 19. Similarly, hCG treatment of mixed glial cultures, from either P0 or P1 neonates, for 3 days lead to a dose-dependent increase in anti-inflammatory prostaglandin (PG), PGD2 and decrease in proinflammatory PGE2. These actions of LHR may be important for neonatal brain development and function as PGE2 inhibits the proliferation of glial cells, while PGD2 may do the exact opposite. Therefore, LHR signaling may be promoting controlled proliferation of glial cells during brain development (94).

While the above cited works cannot conclusively identify the source of LH in the brain, these studies demonstrate the presence of $\mathrm{LH}$ in cognition associated areas and its ability to mediate signaling and behavior. Furthermore, the highlighted in vitro work validates CNS LHR functionality and signaling consistent with cognition and neuroplasticity, both through neurons and glial cells. This said, how the LHR is involved in menopause and ovariectomy-induced cognitive and neuroplasticity loss remains unclear but may be explained through alterations in brain and peripheral levels of LH, as highlighted in the section below.

\section{INVERSE RELATIONSHIP BETWEEN PERIPHERY AND THE BRAIN}

Accumulating research shows that LH levels in the brain may have an inverse relationship to the periphery. For example, in studies of cycling adult female rats, hypothalamic LH decreased during proestrus, when a drastic 10-fold increase in LH occurs in the pituitary and periphery (104). Similarly, LH treatment into the median eminence (ME) of the hypothalamus in intact or castrated males and females significantly decreased both LH levels in the pituitary as well as the periphery (105). In a similar experiment, hCG treatment into the median eminence of hypothalamus in ovariectomized as well as intact mature female rats decreased peripheral LH (106). 
A

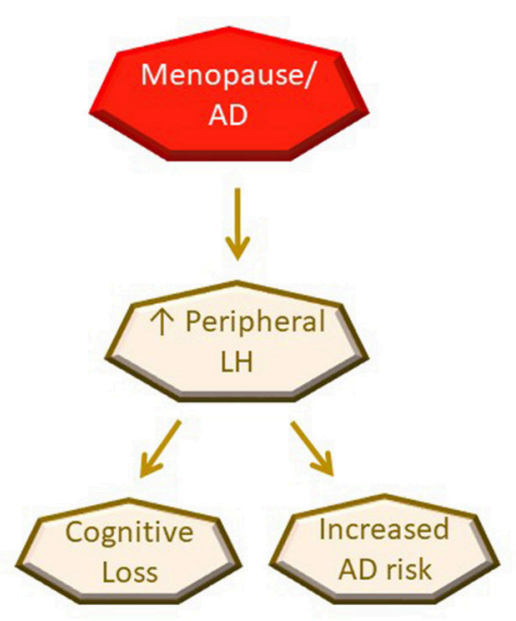

B

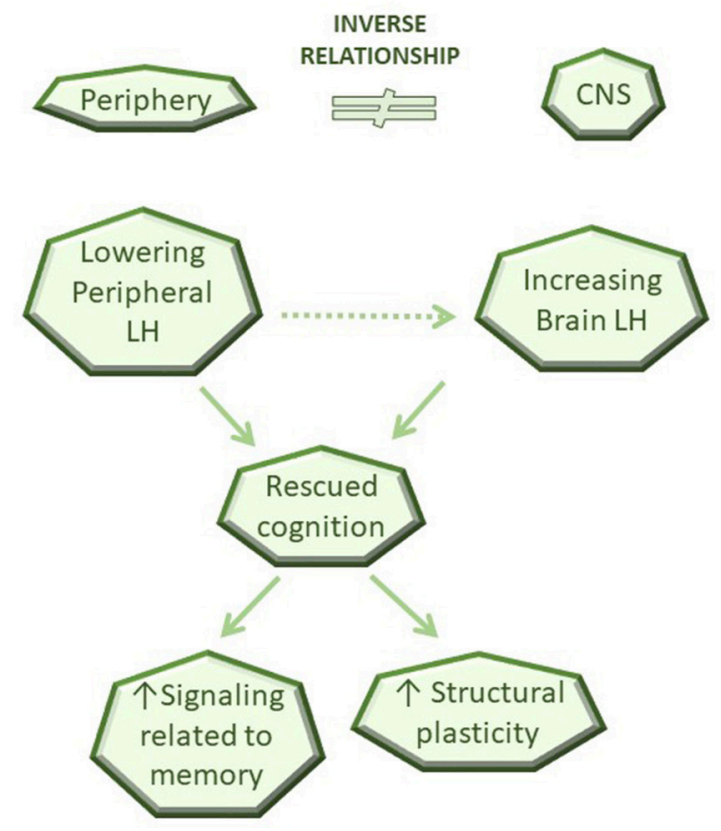

FIGURE 1 | Schematic diagram of current working model for LH action in the CNS. (A) Observation in the literature. (B) Potential mechanisms of LH action.

Additionally, LH mRNA levels are reduced in both the hippocampus and the cortex of human female $\mathrm{AD}$ brains (59), although they are increased in the periphery $(47,48)$. Interestingly, LH immunoreactivity is remarkably reversed when peripheral LH levels are downregulated and lead to improved cognition (59). These experiments, therefore, provide ample support to the idea of inverse relationship between peripheral $\mathrm{LH}$ and central LH, and further suggest that the $\mathrm{LH}$ and hCG in the periphery are capable of self-regulating their levels through short-loop feedback into the brain $(105,107$, 108).

Interestingly, ovariectomized rats have no changes in hypothalamic LH, although the pituitary and serum LH levels are elevated eight-fold (104). Furthermore, the self-regulated decrease in peripheral $\mathrm{LH}$ in response to IV treatment of hCG and hLH seen in rabbits 2 weeks following castrations was absent 6 weeks following castrations, suggesting the sensitivity of the short-loop changes with time after castration (107). This begs the question of whether self-regulation of hypothalamic LH production is more pertinent than gonadal loss, and importantly, whether loss of this "short" feedback in menopause underlies the "critical period" sensitivity observed for estrogen. The fact that the LHR is rapidly internalized in the presence of its ligands (109113) may provide a potential explanation for the loss of shortfeedback loop, as impairments in LHR signaling due to ligandinduced internalization may reduce the ability to signal back to the hypothalamus. This may also explain the work postulating that activation of LHR is deleterious to cognition $(52,62,88,114)$ as the above studies used supraphysiological doses of exogenous
hCG. In one of the studies above, deglycosylated hCG used as the LHR antagonist improved cognition; however, validation of the levels of LHR or verification of full deglycosylation of hCG was not performed (114). Therefore, further studies need to be carried out with careful consideration of LH dose and LHR internalization to clarify the role of LHR in the CNS.

An additional aspect that has confounded our ability to clearly dissect the function of the LHR in the CNS from that of loss of gonadal steroids is the fact that LHR has not been modulated in a brain-specific manner. For example, one article demonstrated that knocking out LHR in an AD mouse model attenuated the pathology and cognitive deficits (115). However, the LHR knockout model was global, not brain-specific, thus early developmental effects due to deficits in sex steroids, which are known in these animals, cannot be separated from the role of LHR loss.

\section{CONCLUSIONS}

Among a multitude of changes that occur with aging, menopause is a clear driver for development of $\mathrm{AD}$ in women. The role of steroid hormones in CNS function and structure, particularly during reproductive stages, is undisputed and here we provide evidence that LH and its receptor are important in CNS function as well as dysfunction as depicted in the working model of $\mathrm{LH}$ action in Figure 1. We also highlight a potential mechanism, specifically the inverse relationship of LH levels in the CNS vs. the periphery, to provide an explanation for the paradox observed between the ability of the LHR to activate cascades associated 
with learning, memory and neuroplasticity, and the findings demonstrating benefits of peripheral $\mathrm{LH}$ downregulation on these aspects. Further investigation is necessary to understand how the inverse relationship of LH between the periphery and the CNS is maintained as well as to identify the molecular mechanisms underlying LH-related memory and plasticity benefits in a CNS-specific manner. Genetic approaches targeting the LHR specifically within the brain are likely to be useful models to conclusively address the role of the LHR in CNS function and structure.

\section{REFERENCES}

1. Alzheimer's Association. 2018 Alzheimer's disease facts and figures. Alzheimers Dement. (2018) 14:367-429. doi: 10.1016/j.jalz.2018.02.001

2. Castellani RJ, Rolston RK, Smith M. Alzheimer disease. Dis Mon. (2011) 56:1-60. doi: 10.1016/j.disamonth.2010.06.001.Alzheimer

3. Maki PM, Henderson VW. Hormone therapy, dementia, and cognition: the Women's Health Initiative 10 years on. Climacteric (2012) 15:256-62. doi: 10.3109/13697137.2012.660613

4. McEwen BS, Alves SE, Bulloch K, Weiland NG. Clinically relevant basic science studies of gender differences and sex hormone effects. Psychopharmacol Bull. (1998) 34:251-9.

5. McEwen BS, Alves SE. Estrogen actions in the central nervous system. Endocr Rev. (1999) 20:279-307. doi: 10.1210/edrv.20.3.0365

6. Hojo Y, Hattori T-A, Enami T, Furukawa A, Suzuki K, Ishii H-T, et al. Adult male rat hippocampus synthesizes estradiol from pregnenolone by cytochromes P45017alpha and P450 aromatase localized in neurons. Proc Natl Acad Sci USA. (2004) 101:865-70. doi: 10.1073/pnas.2630225100

7. Gibbs RB. Estrogen therapy and cognition: a review of the cholinergic hypothesis. Endocr Rev. (2010) 31:224-53. doi: 10.1210/er.2009-0036

8. Bowen RL, Atwood CS. Living and dying for sex: a theory of aging based on the modulation of cell cycle signaling by reproductive hormones. Gerontology (2004) 50:265-90. doi: 10.1159/000079125

9. Launer LJ, Andersen K, Dewey ME, Letenneur L, Ott A, Amaducci LA, et al. Rates and risk factors for dementia and Alzheimer's disease. Neurology (1999) 52:78 LP-78.

10. Andersen K, Launer LJ, Dewey ME, Letenneur L, Ott A, Copeland JRM, et al. Gender differences in the incidence of AD and vascular dementia. Neurology (1999) 53:1992LP-1992.

11. Zandi PP, Carlson MC, Plassman BL, Welsh-Bohmer KA, Mayer LS, Steffens DC, et al. Hormone replacement therapy and incidence of Alzheimer disease in older women: the Cache County Study. J Am Med Assoc. (2002) 288:21239. doi: 10.1097/01.OGX.0000055761.75837.23

12. Kawas C, Resnick S, Morrison A, Brookmeyer R, Corrada M, Zonderman A, et al. A prospective study of estrogen replacement therapy and the risk of developing Alzheimer's disease: the Baltimore Longitudinal Study of Aging. Neurology (1997) 48:1517-21.

13. Hogervorst E, Williams J, Budge M, Riedel W, Jolles J. The nature of the effect of female gonadal hormone replacement therapy on cognitive function in post-menopausal women: a meta-analysis. Neuroscience (2000) 101:485-512. doi: 10.1016/S0306-4522(00)00410-3

14. Tang MX, Jacobs D, Stern Y, Marder K, Schofield P, Gurland B, et al. Effect of oestrogen during menopause on risk and age at onset of Alzheimer's disease. Lancet (1996) 348:429-32.

15. Hogervorst E, Yaffe K, Richards M, Huppert F. Hormone replacement therapy to maintain cognitive function in women with dementia. Cochrane Database Syst. Rev. (2009) 1:CD003799. doi: 10.1002/14651858.CD003799.pub2

16. Rocca WA, Grossardt BR, Shuster LT. Oophorectomy, estrogen, and dementia: a 2014 update. Mol Cell Endocrinol. (2014) 389:7-12. doi: 10.1016/j.mce.2014.01.020.Oophorectomy

17. Henderson VW, Paganini-Hill A, Emanuel CK, Dunn ME, Buckwalter JG. Estrogen replacement therapy in older women. Comparisons between

\section{AUTHOR CONTRIBUTIONS}

All authors listed have made a substantial, direct, and intellectual contribution to the work and approved it for publication.

\section{FUNDING}

Our works cited in this manuscript have been funded by the NIH grant, RF1 AG054654-01.

Alzheimer's disease cases and nondemented control subjects. Arch Neurol. (1994) 51:896-900.

18. Kampen DL, Sherwin BB. Estrogen use and verbal memory in healthy postmenopausal women. Obstet Gynecol. (1994) 83:979-83.

19. Yaffe K, Sawaya G, Lieberburg I, Grady D. Estrogen therapy in postmenopausal women: effects on cognitive function and dementia. J Am Med Assoc. (1998) 279:688-95.

20. Yaffe K, Haan M, Byers A, Tangen C, Kuller L. Estrogen use, APOE, and cognitive decline: evidence of gene-environment interaction. Neurology (2000) 54:1949 LP-1954. doi: 10.1212/WNL.54.10.1949

21. Sherwin BB. Estrogen and/or androgen replacement therapy and cognitive functioning in surgically menopausal women. Psychoneuroendocrinology (1988) 13:345-57. doi: 10.1016/0306-4530(88)90060-1

22. Sherwin BB. Can estrogen keep you smart? Evidence from clinical studies. $J$ Psychiatry Neurosci. (1999) 24:315-21.

23. Phillips SM, Sherwin BB. Effects of estrogen on memory function in surgically menopausal women. Psychoneuroendocrinology (1992) 17:485-95.

24. Shumaker SA, Legault C, Rapp SR, Thal L, Wallace RB, Ockene JK, et al. Estrogen plus progestin and the incidence of dementia and mild cognitive impairment in postmenopausal women: the women's health initiative memory study: a randomized controlled trial. JAMA (2003) 289:2651-62. doi: 10.1001/jama.289.20.2651

25. Shumaker SA, Legault C, Rapp SR, Thal L, Lane DS, Fillit H, et al. Conjugated equine estrogens and incidence of probable dementia and mild cognitive impairment in postmenopausal women Women's Health Initiative Memory Study. JAMA (2004) 291:2947-58. doi: 10.1001/jama.291.24.2947

26. Espeland MA, Rapp SR, Shumaker SA, Brunner R, Manson JE, Sherwin $\mathrm{BB}$, et al. Conjugated equine estrogens and global cognitive function in postmenopausal women Women's Health Initiative Memory Study. JAMA (2004) 291:2959-68. doi: 10.1001/jama.291.24.2959

27. Resnick SM, Henderson VW. Hormone therapy and risk of Alzheimer disease: a critical time. J Am Med Assoc. (2002) 288:2170-2. doi: 10.1001/jama.288.17.2170

28. Henderson VW. Hormone therapy and Alzheimer's disease: benefit or harm? Expert Opin Pharmacother. (2004) 5:389-406. doi: 10.1517/14656566.5.2.389

29. Sherwin BB. Estrogen and cognitive functioning in women: lessons we have learned. Behav Neurosci. (2012) 126:123-7. doi: 10.1037/a0025539

30. Shao H, Breitner JCS, Whitmer RA, Wang J, Hayden K, Wengreen $\mathrm{H}$, et al. Hormone therapy and Alzheimer disease dementia: new findings from the cache county study. Neurology (2012) 79:1846-52. doi: 10.1212/WNL.0b013e318271f823

31. Singh M, Simpkins JW, Bimonte-Nelson HA, Brinton RD. Window of opportunity for estrogen and progestin intervention in brain aging and Alzheimer's disease. Brain Res. (2013) 1514:1-2. doi: 10.1016/j.brainres.2013.04.044

32. Gibbs R. Long-term treatment with estrogen and progesterone enhances acqui- sition of a spatialmemory task by ovariectomized aged rats. Neurobiol Aging (2000) 21:107-16. doi: 10.1016/S0197-4580(00)00103-2

33. Lacreuse A, Wilson ME, Herndon JG. Estradiol, but not raloxifene, improves aspects of spatial working memory in aged ovariectomized rhesus monkeys. Neurobiol Aging (2002) 23:589-600. doi: 10.1016/S0197-4580(02) 00002-7 
34. Gibbs RB, Gabor R. Estrogen and cognition: applying preclinical findings to clinical perspectives. J Neurosci Res. (2003) 74:637-43. doi: 10.1002/jnr.10811

35. Zhao L, Chen S, Ming Wang J, Brinton RD. 17beta-estradiol induces Ca2+ influx, dendritic and nuclear $\mathrm{Ca} 2+$ rise and subsequent cyclic AMP response element-binding protein activation in hippocampal neurons: a potential initiation mechanism for estrogen neurotrophism. Neuroscience (2005) 132, 299-311. doi: 10.1016/j.neuroscience.2004.11.054

36. Brinton RD. The healthy cell bias of estrogen action: mitochondrial bioenergetics and neurological implications. Trends Neurosci. (2008) 31:52937. doi: 10.1016/j.tins.2008.07.003

37. Jezierski MK, Sohrabji F. Neurotrophin expression in the reproductively senescent forebrain is refractory to estrogen stimulation. Neurobiol Aging (2001) 22:311-21. doi: 10.1016/S0197-4580(00)00230-X

38. Markowska AL, Savonenko AV. Effectiveness of estrogen replacement in restoration of cognitive function after long-term estrogen withdrawal in aging rats. J. Neurosci. (2002) 22:10985-95. doi: 10.1523/JNEUROSCI.22-24-10985.2002

39. Espeland MA, Shumaker SA, Leng I, Manson JE, Brown CM, LeBlanc ES, et al. Long-term effects on cognitive function of postmenopausal hormone therapy prescribed to women aged 50 to 55 years. JAMA Intern Med. (2013) 173:1429-36. doi: 10.1001/jamainternmed.2013.7727

40. Gleason CE, Dowling NM, Wharton W, Manson JAE, Miller VM, Atwood CS, et al. Effects of hormone therapy on cognition and mood in recently postmenopausal women: findings from the randomized, controlled KEEPS-cognitive and affective study. PLoS Med. (2015) 12:e1833. doi: 10.1371/journal.pmed.1001833

41. Henderson VW, St John JA, Hodis HN, McCleary CA, Stanczyk FZ, Shoupe D, et al. Cognitive effects of estradiol after menopause. Neurology (2016) 87:699-708. doi: 10.1212/WNL.0000000000002980

42. Imtiaz B, Tuppurainen M, Rikkonen T, Kivipelto M, Soininen H, Kröger H, et al. Postmenopausal hormone therapy and Alzheimer disease. Neurology (2017) 88:1062-8. doi: 10.1212/WNL.0000000000003696

43. Chakravarti S, Collins WP, Forecast JD, Newton TR, Oram DH, Studd JWW. Hormonal profiles after the menopause. Br Med J. (1976) 2:784-7. doi: $10.1136 /$ bmj.2.6039.784

44. Neaves WB, Johnson L, Porter JC, Parker CRJ, Petty CS. Leydig cell numbers, daily sperm production, and serum gonadotropin levels in aging men. J Clin Endocrinol Metab. (1984) 59:756-63. doi: 10.1210/jcem-59-4-756

45. Hyde Z, Flicker L, Almeida OP, McCaul KA, Jamrozik K, Hankey GJ, et al. Higher luteinizing hormone is associated with poor memory recall: the health in men study. J Alzheimers Dis. (2010) 19:943-51. doi: 10.3233/JAD-2010-1342

46. Rodrigues MA, Verdile G, Foster JK, Hogervorst E, Joesbury K, Devine A, et al. Gonadotropins and cognition in older women. J Alzheimers Dis. (2008) 13:267-74. doi: 10.3233/JAD-2008-13304

47. Short RA, Bowen RL, O'Brien PC, Graff-Radford NR. Elevated gonadotropin levels in patients with Alzheimer disease. Mayo Clin Proc. (2001) 76:906-9. doi: 10.4065/76.9.906

48. Butchart C, Ismailoglu F, Myint PK, Musonda P, Lunt CJ, Pai Y, et al. Identification of possible determinants of inpatient mortality using Classification and Regression Tree (CART) analysis in hospitalized oldest old patients. Arch Gerontol Geriatr. (2013) 56:188-91.doi: 10.1016/j.archger.2012.07.005

49. Hogervorst E, Bandelow S, Combrinck M, Smith AD. Low free testosterone is an independent risk factor for Alzheimer's disease. Exp. Gerontol. (2004) 39:1633-9. doi: 10.1016/j.exger.2004.06.019

50. Verdile G, Yeap BB, Clarnette RM, Dhaliwal S, Burkhardt MS, Chubb SAP, et al. Luteinizing hormone levels are positively correlated with plasma amyloid-beta protein levels in elderly men. J Alzheimers Dis. (2008) 14:201-8. doi: 10.3233/JAD-2008-14208

51. Verdile G, Laws SM, Henley D, Ames D, Bush AI, Ellis KA, et al. Associations between gonadotropins, testosterone and beta amyloid in men at risk of Alzheimer's disease. Mol Psychiatry (2014) 19:69-75. doi: $10.1038 / \mathrm{mp} .2012 .147$

52. Verdile G, Asih PR, Barron AM, Wahjoepramono EJ, Ittner LM, Martins RN. The impact of luteinizing hormone and testosterone on beta amyloid $(\mathrm{A} \beta)$ accumulation: animal and human clinical studies. Horm Behav. (2015) 76:81-90. doi: 10.1016/j.yhbeh.2015.05.020
53. Casadesus G, Milliken EL, Webber KM, Bowen RL, Lei Z, Rao CV, et al. Increases in luteinizing hormone are associated with declines in cognitive performance. Mol Cell Endocrinol. (2007) 269:107-11. doi: 10.1016/j.mce.2006.06.013

54. Wahjoepramono EJ, Wijaya LK, Taddei K, Bates KA, Howard M, Martins G, et al. Direct exposure of guinea pig CNS to human luteinizing hormone increases cerebrospinal fluid and cerebral beta amyloid levels. Neuroendocrinology (2011) 94:313-22. doi: 10.1159/0003 30812

55. Berry AS, Tomidokoro Y, Ghiso J, Thornton J. Human chorionic gonadotropin (a luteinizing hormone homologue) decreases spatial memory and increases brain amyloid-beta levels in female rats. Horm Behav. (2008) 54:143-52. doi: 10.1016/j.yhbeh.2008.02.006

56. Barron AM, Verdile G, Taddei K, Bates KA, Martins RN. Effect of chronic hCG administration on Alzheimer's-related cognition and A beta accumulation in PS1KI mice. Endocrinology (2010) 151:5380-8. doi: 10.1210/en.2009-1168

57. Casadesus G, Webber KM, Atwood CS, Pappolla M, Perry G, Bowen RL, et al. Luteinizing hormone modulates cognition and amyloid-beta deposition in Alzheimer APP transgenic mice. Biochim Biophys Acta (2006) 1762:447-52. doi: 10.1016/j.bbadis.2006.01.008

58. Bryan KJ, Mudd JC, Richardson SL, Chang J, Lee HG, Zhu X, et al. Downregulation of serum gonadotropins is as effective as estrogen replacement at improving menopause-associated cognitive deficits. J Neurochem. (2010) 112:870-81. doi: 10.1111/j.1471-4159.2009.06502.x

59. Palm R, Chang J, Blair J, Garcia-Mesa Y, Lee H, Castellani RJ, et al. Downregulation of serum gonadotropins but not estrogen replacement improves cognition in aged-ovariectomized $3 \times \mathrm{xTg} \mathrm{AD}$ female mice. $J$ Neurochem. (2014) 130:115-25. doi: 10.1111/jnc.12706

60. Blair JA, Palm R, Chang J, McGee H, Zhu X, Wang X, et al. Luteinizing hormone downregulation but not estrogen replacement improves ovariectomy-associated cognition and spine density loss independently of treatment onset timing. Horm Behav. (2016) 78:60-6. doi: 10.1016/j.yhbeh.2015.10.013

61. McConnell SE, Alla J, Wheat E, Romeo RD, McEwen B, Thornton JE. The role of testicular hormones and luteinizing hormone in spatial memory in adult male rats. Horm Behav. (2012) 61:479-86. doi: 10.1016/j.yhbeh.2012.01.003

62. Ziegler SG, Thornton JE. Low luteinizing hormone enhances spatial memory and has protective effects on memory loss in rats. Horm Behav. (2010) 58:705-13. doi: 10.1016/j.yhbeh.2010.07.002

63. Telegdy G, Adamik A, Tanaka M, Schally AV. Effects of the LHRH antagonist Cetrorelix on affective and cognitive functions in rats. Regul Pept. (2010) 159:142-7. doi: 10.1016/j.regpep.2009.08.005

64. Telegdy G, Tanaka M, Schally AV. Effects of the LHRH antagonist Cetrorelix on the brain function in mice. Neuropeptides (2009) 43:229-34. doi: 10.1016/j.npep.2009.03.001

65. Bowen RL, Perry G, Xiong C, Smith MA, Atwood CS. A clinical study of lupron depot in the treatment of women with $\mathrm{AD}$ : preservation of cognitive function in patients taking an acetylcholinesterase inhibitor and treated with high dose lupron over 48 weeks. J Alzheimer's Dis. (2015) 34:549-60. doi: 10.3233/JAD-141626

66. Emanuele NV, Anderson J, Andersen E, Connick E, Baker G, Kirsteins L, et al. Extrahypothalamic brain luteinizing hormone: characterization by radioimmunoassay, chromatography, radioligand assay and bioassay. Neuroendocrinology (1983) 36, 254-260.

67. Glass JD, McClusky ME. Immunoreactive luteinizing hormone-containing neurons in the brain of the white-footed mouse, Peromyscus leucopus. Experientia (1987) 43:188-90.

68. Lei ZM, Rao CV, Kornyei JL, Licht P, Hiatt ES. Novel expression of human chorionic gonadotropin/luteinizing hormone receptor gene in brain. Endocrinology (1993) 132:2262-70.

69. Apaja PM, Harju KT, Aatsinki JT, Petäjä-Repo UE, Rajaniemi HJ. Identification and structural characterization of the neuronal luteinizing hormone receptor associated with sensory systems. J Biol Chem. (2004) 279:1899-906. doi: 10.1074/jbc.M311395200

70. Hämäläinen T, Poutanen M, Huhtaniemi I. Age- and sex-specific promoter function of a 2-kilobase $5^{\prime}$-flanking sequence of themurine luteinizing 
hormone receptor gene in transgenic mice. Endocrinology (1999) 140:53229.

71. Ascoli M, Fanelli F, Segaloff DL. The lutropin/choriogonadotropin receptor, A 2002 perspective. Endocr Rev. (2002) 23:141-74. doi: 10.1210/edrv.23.2.0462

72. Herrlich A, Kühn B, Grosse R, Schmid A, Schultz G, Gudermann T. Involvement of Gs and Gi proteins in dual coupling of the luteinizing hormone receptor to adenylyl cyclase and phospholipase C. J Biol Chem. (1996) 271:16764-72.

73. Gudermann T, Nichols C, Levy FO, Birnbaumer M, Birnbaumer L. $\mathrm{Ca} 2+$ mobilization by the LH receptor expressed in Xenopus oocytes independent of 3,5'-cyclic adenosine monophosphate formation: evidence for parallel activation of two signaling pathways. Mol Endocrinol. (1992) 6:272-8.

74. Gudermann T, Birnbaumer M, Birnbaumer L. Evidence for dual coupling of the murine luteinizing hormone receptor to adenylyl cyclase and phosphoinositide breakdown and Ca2+ mobilization. J Biol Chem. (1992) 267:4479-88.

75. Lei ZM, Rao CV. Novel presence of luteinizing hormone/human chorionic gonadotropin (hCG) receptors and the down-regulating action of hCG on gonadotropin- releasing hormone gene expression in immortalized hypothalamic GT1-7 neurons. Mol Endocrinol. (1994) 8:1111-21. doi: $10.1210 /$ mend.8.8.7997235

76. Zhang W, Lei ZM, Rao CV. Immortalized hippocampal cells contain functional luteinizing hormone/human chorionic gonadotropin receptors. Life Sci. (1999) 65:2083-98. doi: 10.1016/S0024-3205(99)00474-9

77. Atkins CM, Selcher JC, Petraitis JJ, Trzaskos JM, Sweatt JD. The MAPK cascade is required for mammalian associative learning. Nat Neurosci. (1998) 1:602-9.

78. English JD, Sweatt JD. A requirement for the mitogen-activated protein kinase cascade in hippocampal long term potentiation. J Biol Chem. (1997) 272:19103-6.

79. Matsuzaki M, Honkura N, Ellis-Davies GC, Kasai H. Structural basis of long-term potentiation in single dendritic spines. Nature (2004) 429:761-6. doi: 10.1038 /nature 02617

80. Kasai H, Matsuzaki M, Noguchi J, Yasumatsu N, Nakahara H. Structurestability-function relationships of dendritic spines. Trends Neurosci. (2003) 26:360-8.doi: 10.1016/S0166-2236(03)00162-0

81. Roche KW, O’Brien RJ, Mammen AL, Bernhardt J, Huganir RL. Characterization of multiple phosphorylation sites on the AMPA receptor GluR1 subunit. Neuron (1996) 16:1179-88.

82. Barria A, Muller D, Derkach V, Griffith LC, Soderling TR. Regulatory phosphorylation of AMPA-type glutamate receptors by CaMKII during long-term potentiation. Science (1997) 276:2042-5.

83. Mammen AL, Kameyama K, Roche KW, Huganir RL. Phosphorylation of the alpha-amino-3-hydroxy-5-methylisoxazole-4-propionic acid receptor GluR1 subunit by calcium/calmodulin-dependent kinase II. J Biol Chem. (1997) 272:32528-33.

84. Lee HK, Barbarosie M, Kameyama K, Bear MF, Huganir RL. Regulation of distinct AMPA receptor phosphorylation sites during bidirectional synaptic plasticity. Nature (2000) 405:955-9. doi: 10.1038/350 16089

85. Nusser Z, Lujan R, Laube G, Roberts JD, Molnar E, Somogyi P. Cell type and pathway dependence of synaptic AMPA receptor number and variability in the hippocampus. Neuron (1998) 21:545-59.

86. Matsuzaki M, Ellis-Davies GC, Nemoto T, Miyashita Y, Iino M, Kasai H. Dendritic spine geometry is critical for AMPA receptor expression in hippocampal CA1 pyramidal neurons. Nat Neurosci. (2001) 4:1086-92. doi: $10.1038 / \mathrm{nn} 736$

87. Jezierski MK, Sohrabji F. Estrogen enhances retrograde transport of brainderived neurotrophic factor in the rodent forebrain. Endocrinology (2003) 144:5022-9. doi: 10.1210/en.2003-0724

88. Lukacs H, Hiatt ES, Lei ZM, Rao CV. Peripheral and intracerebroventricular administration of human chorionic gonadotropin alters several hippocampus-associated behaviors in cycling female rats. Horm Behav. (1995) 29:42-58.

89. Ondo JG, Mical RS, Porter JC. Passage of Radioactive Substances from CSF to Hypophysial Portal Blood1. Endocrinology (1972) 91:1239-46.
90. McCormick JB. Gonadotrophin in urine and spinal fluid; quantitative studies for chorionic moles and choriocarcinomas. Obstet Gynecol. (1954) 3:58-66.

91. Tashima CK, Timberger R, Burdick R, Leavy M, Rawson RW. Cerebrospinal fluid titer of chorionic gonadotropin in patients with intracranial metastatic choriocarcinoma. J Clin Endocrinol Metab. (1965) 25:1493-5. doi: 10.1210/jcem-25-11-1493

92. Bagshawe KD, Orr AHH, Rushworth AGJ. Relationship between concentrations of human chorionic gonadotropin in plasma and cerebrospinal fluid. Nature (1968) 217:950-1.

93. Gallo RV, Johnson JH, Kalra SP, Whitmoyer DI, Sawyer CH. Effects of luteinizing hormone on multiple-unit activity in the rat hippocampus. Neuroendocrinology (1972) 9:149-57. doi: 10.1159/000122046

94. AL-Hader AA, Lei ZM, Rao CV. Novel expression of functional luteinizing hormone/chorionic gonadotropin receptors in cultured glial cells from neonatal rat brains. Biol Reprod. (1997) 56:501-7. doi: 10.1095/biolreprod56.2.501

95. AL-Hader AA, Lei ZM, Rao CV. Neurons from fetal rat brains contain functional luteinizing hormone/chorionic gonadotropin receptors. Biol Reprod. (1997) 56:1071-6. doi: 10.1095/biolreprod,56.5.1071

96. Mak GK, Enwere EK, Gregg C, Pakarainen T, Poutanen M, Huhtaniemi I, et al. Male pheromone-stimulated neurogenesis in the adult female brain: possible role in mating behavior. Nat Neurosci. (2007) 10:1003-11. doi: $10.1038 / \mathrm{nn} 1928$

97. Zhao C, Deng W, Gage FH. Mechanisms and Functional Implications of Adult Neurogenesis. Cell (2008) 132:645-60. doi: 10.1016/j.cell.2008.01.033

98. Yang E-J, Nasipak BT, Kelley DB. Direct action of gonadotropin in brain integrates behavioral and reproductive functions. Proc Natl Acad Sci USA. (2007) 104:2477-82. doi: 10.1073/pnas.0608391104

99. Menon KMJ, Menon B. Structure, function and regulation of gonadotropin receptors - A perspective. Mol Cell Endocrinol. (2012) 356:88-97. doi: 10.1016/j.mce.2012.01.021

100. McFarland KC, Sprengel R, Phillips HS, Kohler M, Rosemblit N, Nikolics $\mathrm{K}$, et al. Lutropin-choriogonadotropin receptor: an unusual member of the G protein-coupled receptor family. Science (1989) 245:494-9. doi: $10.1126 /$ science. 2502842

101. Meng XL, Rennert OM, Chan WY. Human chorionic gonadotropin induces neuronal differentiation of PC12 cells through activation of stably expressed lutropin/choriogonadotropin receptor. Endocrinology (2007) 148:5865-73. doi: 10.1210/en.2007-0941

102. Gallego MJ, Porayette P, Kaltcheva MM, Bowen RL, Vadakkadath Meethal S, Atwood CS. The pregnancy hormones human chorionic gonadotropin and progesterone induce human embryonic stem cell proliferation and differentiation into neuroectodermal rosettes. Stem Cell Res Ther. (2010) 1:28. doi: $10.1186 /$ scrt28

103. Movsas TZ, Weiner RL, Greenberg MB, Holtzman DM, Galindo R. Pretreatment with human chorionic gonadotropin protects the neonatal brain against the effects of hypoxic-ischemic injury. Front Pediatr. (2017) 5:232. doi: 10.3389/fped.2017.00232

104. Emanuele N, Oslapas R, Connick E, Kirsteins L, Lawrence AM. Hypothalamic LH may play a role in control of pituitary LH release. Neuroendocrinology (1981) 33:12-7. doi: 10.1111/j.1752-1688.2007.00005.x

105. David MA, Fraschini F, Martini L. Control of LH secretion: role of a "Short" feedback mechanism1. Endocrinology (1966) 78:55-60. doi: 10.1210/endo-78-1-55

106. Hirono $M$, Igarashi $M$, Matsumoto $S$. The direct effect of HCG upon pituitary gonadotrophin secretion. Endocrinology (1972) 90:1214-9. doi: 10.1210/endo-90-5-1214

107. Molitch M, Edmonds M, Jones EE, Odell WD. Short-loop feedback control of luteinizing hormone in the rabbit. Am J Physiol. (1976) 230:907-10.

108. Patritti-laborde N, Wolfsen ADAR, Heber D, Odell WD. Luteinizing hormone in the rabbit. J Clin Invest. (1979) 64:1066-9.

109. Hu Z. Hormonal regulation of LH receptor mRNA and expression in the rat ovary. FEBS Lett. (1990) 274:181-4. doi: 10.1016/0014-5793(90)81359-V

110. Segaloff DL, Sprengel R, Nikolics K, Ascoli M. Structure of the lutropin/choriogonadotropin receptor. Recent Prog Horm Res. (1990) 46:261-3.

111. Peegel H, Randolph JJ, Midgley AR, Menon KM. In situ hybridization of luteinizing hormone/human chorionic gonadotropin receptor messenger 
ribonucleic acid during hormone-induced down-regulation and the subsequent recovery in rat corpus luteum. Endocrinology (1994) 135:104451. doi: 10.1210/endo.135.3.8070346

112. Min KS, Liu X, Fabritz J, Jaquette J, Abell AN, Ascoli M. Mutations that induce constitutive activation and mutations that impair signal transduction modulate the basal and/or agonist-stimulated internalization of the lutropin/choriogonadotropin receptor. J Biol Chem. (1998) 273:34911-9. doi: 10.1074/jbc.273.52.34911

113. Kishi M, Liu X, Hirakawa T, Reczek D, Bretscher A, Ascoli M. Identification of two distinct structural motifs that, when added to the C-terminal tail of the rat $\mathrm{LH}$ receptor, redirect the internalized hormone-receptor complex from a degradation to a recycling pathway. Mol Endocrinol. (2001) 15:1624-35. doi: 10.1210/me.15.9.1624

114. Burnham V, Sundby C, Laman-Maharg A, Thornton J. Luteinizing hormone acts at the hippocampus to dampen spatial memory. Horm Behav. (2017) 89:55-63. doi: 10.1016/j.yhbeh.2016.11.007
115. Lin J, Li X, Yuan F, Lin L, Cook CL, Rao CV, et al. Genetic ablation of luteinizing hormone receptor improves the amyloid pathology in a mouse model of alzheimer disease. J Neuropathol Exp Neurol. (2010) 69:253-61. doi: 10.1097/NEN.0b013e3181d072cf

Conflict of Interest Statement: The authors declare that the research was conducted in the absence of any commercial or financial relationships that could be construed as a potential conflict of interest.

Copyright (c) 2018 Bhatta, Blair and Casadesus. This is an open-access article distributed under the terms of the Creative Commons Attribution License (CC BY). The use, distribution or reproduction in other forums is permitted, provided the original author(s) and the copyright owner(s) are credited and that the original publication in this journal is cited, in accordance with accepted academic practice. No use, distribution or reproduction is permitted which does not comply with these terms. 